\title{
Africa, the Arabian Gulf and Asia: Changing Dynamics in Contemporary West Africa's Political Economy
}

\section{Citation}

Akyeampong, Emmanuel K. 2011. "Africa, the Arabian Gulf and Asia: changing dynamics in contemporary west Africa's political economy." Journal of African Development 13 (1): 85-115.

\section{Published Version}

http://www.jadafea.com/wp-content/uploads/2014/07/JAD_vol13_ch5complete.pdf

\section{Permanent link}

http://nrs.harvard.edu/urn-3:HUL.InstRepos:14018060

\section{Terms of Use}

This article was downloaded from Harvard University's DASH repository, and is made available under the terms and conditions applicable to Open Access Policy Articles, as set forth at http:// nrs.harvard.edu/urn-3:HUL.InstRepos:dash.current.terms-of-use\#OAP

\section{Share Your Story}

The Harvard community has made this article openly available.

Please share how this access benefits you. Submit a story.

Accessibility 


\title{
Africa, the Arabian Gulf and Asia: Changing Dynamics in Contemporary West Africa's Political Economy*
}

\author{
Emmanuel Akyeampong \\ History Department, Harvard University \\ 1730 Cambridge Street \\ Cambridge, MA 02138 \\ Email:akyeamp@fas.harvard.edu
}

* The author is grateful to Dr. William Baah-Boateng for his assistance with the tables and figures in this paper, and to the two anonymous reviewers of this journal for their invaluable comments. 


\begin{abstract}
The last two to three decades have witnessed significant transformation in West Africa's relations to the Arabian Gulf and Asia. While ties to countries such as Saudi Arabia are historic, economic liberalization since the 1980s has introduced new trading partners and some unexpected developments. The outcome of these recent developments can be startling: so in Ghana, for example, India and China have overtaken the United Kingdom, the former colonial power, in investments and the number of operating companies. The United Arab Emirates (UAE) ranks third in the cumulative value of foreign direct investments in Ghana since 1994. This paper is an historian's attempt to provide context, some perspective and to probe the implications of these emerging patterns for the political economy of West Africa. It uses Ghana under the Kufuor regime (2000-2008) as a case study of how one West African government engaged the new economic opportunities and the growing importance of Arab and Asian trading partners and investors in the climate of South-South cooperation.
\end{abstract}

\title{
INTRODUCTION
}

This paper examines the place of Asia and the Arabian Gulf in the changing political economy of contemporary West Africa. Though situated in the historical context of post-colonial Africa, the focus is on the last decade, a decade where relatively new economic players such as China and the United Arab Emirates (UAE) have become economically significant as investors and trading partners for West Africa. A conference on Africa and the Indian Ocean should highlight East Africa, the historical and natural trading partner of the Arab and Asian worlds (Middleton, 1992; Pearson, 1998; Alpers, 2009). But the view from West Africa is no less intriguing, where the insertion of trading partners and the sourcing of investment from the Indian Ocean has been more reflexive. Within West Africa a closer look at Ghana under the administration of President John A. Kufuor (2000-2008) is particularly fascinating, as the country declared the first decade of the new millennium as the "Golden Age of Business" and positioned itself as the "Gateway to West Africa" or the trade zone of the Economic Community of West 
African States (ECOWAS). What this confluence offers is an important opportunity to interrogate emerging countries and regions exploring new business opportunities in a South-South relationship in an era where development outside the confines of the West has become a possibility. Indeed, South-South trade or business has enabled the redefinition of African economies away from the neocolonial mooring, and African states, the private sector, and small-scale traders have embraced with enthusiasm the opportunities represented by countries like the UAE, Kuwait, Saudi Arabia, China, India and Malaysia.

Aside from the relevant published literature, this paper draws on newspaper coverage by one major state-run newspaper (Daily Graphic) and one leading private newspaper (The Ghanaian Chronicle) to reconstruct Asian and Arab economic activities in Ghana between 2000 and 2008. Through the newspaper coverage, I attempt to piece together the investment philosophy of the Kufuor administration as outlined in several presidential-led trade missions to the Asian and the Arab worlds. Some of the clearest presentations of the administration's trade and investment vision for the country were stated during these visits. Policy statements, formulation, and implementation are, of course, separate spheres, and we must bear this in mind as we discuss the trade and investment strategies outlined in these overseas trips. I draw on statistics on foreign direct investment compiled by the Ghana Investment Promotion Center during this period to examine the success of the government's investment pitches. These statistics are cumulative for the period from September 1994 to December 2009, and I use these statistics to track country of origin, the value of investments, and the sectors of investment. I cannot comment on the comprehensiveness of these statistics. ${ }^{1}$ The rest of the paper is divided into five parts: "the post-colonial context" provides a brief overview of African political economy since independence and Arab and Asian engagement; "the age of out-sourcing" discusses international production in the post-1980s and the emergence of China as the factory of the West; "an alternative economic paradigm" examines the opportunities presented by Asian and Arab Gulf countries in West Africa in the past decade; then comes our case study of Ghana's attempt to position itself as the gateway to West Africa; and finally the conclusion. In the conclusion I offer some reflections on Kufuor's trade and investment strategy. Though his presidency witnessed 
high growth rates with real GDP growth averaging 6.2 per cent between 2005 and 2007 and a World Bank report in 2008 ranked Ghana the best place for business in West Africa, his party, the New Patriotic Party (NPP), lost the 2008 elections to the opposition National Democratic Congress (NDC), which many considered a referendum on Kufuor's government.

\section{THE POST-COLONIAL CONTEXT}

The 1960s was the decade of political independence in sub-Saharan Africa. In the late 1950s a few British colonies had become independent, Sudan and Ghana being pioneers. France granted blanket independence to her colonies in 1960, after insisting for years that independence was not part of its political agenda as the African colonies were part of overseas France. Decolonization continued in spurts and starts after the 1960s, when most African colonies became independent, with South Africa and Namibia representing some of the last colonies to become independent in the early 1990s. Examining the position of British and French business on independence, Anthony Hopkins described decolonization as the greatest triumph of European colonialism in the way European economic interests were protected by incoming African nationalist governments without the cost of maintaining colonies (Hopkins, 1973). Decolonization was a paradoxical experience, exhilarating in many ways and frustrating in others. One area of frustration was the inability of political independence to translate into economic growth and autonomy. This was in spite of the prevalence of "modernization" theory, which held out the prospect in the early years of independence that the transfer of western capital (investment) and technology would result in African industrialization. ${ }^{2}$

Some in the first generation of African leaders did choose to experiment with socialism, not necessarily persuaded by the variant in Eastern Europe and China, but convinced that the need for rapid development required a prominent role for the state. "Development" broadly described the huge needs within newly independent African countries to provide free or subsidized good education, health, jobs, good housing, access to consumer goods, and an improved quality of life. Nationalist agitation had generated high expectations among African populations, and the new African leaders were faced not just with the need for economic growth, but an equitable distribution of resources 
across national populations in ways that met the developmental agenda. For Julius Nyerere in Tanzania and Leopold Senghor in Senegal, some African form of socialism that avoided the pitfalls of social and political inequalities associated with capitalism was desirable. Others like Kwame Nkrumah of Ghana and Sekou Toure of Guinea did find Marxism-Leninism attractive. As Ralph Austen points out in his comparison of capitalist and socialist economies in the first decades of African independence, even states that went down the capitalist path chose this model more by default than by design, uncertain that the market theory of spontaneous and piecemeal change could deliver on the huge and urgent social and economic needs that confronted newly independent African nations. In both "socialist" and capitalist" African economies, the state played a large role, accounting for 56 per cent of the public sector in Ghana at the time of Nkrumah's overthrow in 1966, and 35 per cent in the Ivory Coast (the model of capitalism in West Africa) between 1968 and 1975 (Austen, 1987, pp. 224-261). The failure of the socialist experiments in countries such as Ghana and Tanzania strengthened capitalism as an alternative economic model and the prescription for countries such as Ghana that turned early to the World Bank and the International Monetary Fund (IMF) for assistance. Ghana's was bankrupt in 1966. But there were equally trenchant critiques of capitalism by the 1970 s by the dependency theorists, who doubted the ability of capitalism to generate economic growth in peripheral former colonies, just as the Marxists doubted the ability of capitalism to deliver on development (equity) as distinct from economic growth. Both viewed colonialism as responsible for laying the foundation for Africa's underdevelopment. ${ }^{3}$

African countries borrowed money extensively and incautiously in the 1960s and 1970s in the effort to industrialize and diversify their economies and to build prestigious projects that underscored their status as new nations. Celestin Monga (2006) points to how the presence of petrodollars in these decades and the presumption among bankers that countries could no go bankrupt - not even poor African countries - supported an environment of liberal loans. The high prices enjoyed by African commodity exports in the 1960s and 1970s underpinned this financial optimism. Development economics in the post-World War II period had normalized deficit financing as a strategy for jump-starting economic growth (Killick, 2003). Setbacks occurred with the Sahelian drought of the 
early 1970s that undermined agriculture, and the OPEC oil crisis of the same decade that plunged most African non-oil producing countries into large external debt. The cost of borrowing money went up astronomically in the late 1970s and 1980s. Patrick Manning (1998, p. 126) points to how interest rates jumped from as low as 3 per cent in the 1960s to as high as 20 per cent in the second half of the 1970s. Monga emphasizes the decline in the effectiveness of the Organization of Petroleum Exporting Countries (OPEC) as a cartel in the 1980s and hence it being not so flush with petrodollars, and the extensive military buildup under the Regan government in the United States with its concomitant borrowing as central to the changing international financial climate of the 1980s and the credit crunch for African countries (Monga, 2006, pp. 244-5; Cooper, 2002, pp. 91-132). By the early 1980s, several African countries had accumulated heavy foreign debts and had turned to the World Bank and the International Monetary Fund for assistance in debt repayment. This was the context for the imposition of Structural Adjustment Programs (SAPs) by the Bretton Woods institutions.

Monga points out that the need for "structural" or "macroeconomic" adjustment had come about because African economies had been unsuccessful in diversifying their economies from the colonial base. They remained reliant on the export of a few primary commodities, a sector subject to unpredictable price fluctuations and for which markets in the years from 1970 to 2000 became very unstable. ${ }^{4}$ Large state projects bloated civil services tasked with oversight. A few countries had a light manufacturing sector in import-substitution, but outside of South Africa no sub-Saharan country had managed to industrialize. In general, African economies were marked by low productivity and high consumption of imported goods. SAPs aimed at stabilizing African economies facing serious balance of payments and unable to attract foreign investment or secure loans. Stabilization was to be followed by adjustment geared towards promoting growth. One of the objectives of SAPs was to diversify African economies, though they have not been successful in this. Under SAPs, African countries were pushed more forcefully towards free market enterprise: exchange rate regimes were liberalized to correct over-valued currencies, governments retrenched bloated state bureaucracies, removed obstacles to free trade, privatized state-owned-enterprises, and removed state subsidies in areas such as health and education; in short, to bring about a contraction of domestic spending more 
in line with a country's income. Coinciding with the internationalization of production that has witnessed the emergence of countries such as China and India as sites of production for Western countries, the unintended outcome of economic liberalization in Africa from the 1980s was to diversify Africa's networks of trade away from the prior dependence on Europe and North America (Meagher, 2003). The depreciation of domestic currencies following the liberalization of exchange rate regime, inflation, and declining real incomes encouraged the sourcing of cheaper consumer goods from nontraditional trading partners such as Asian and the Arabian Gulf countries.

Many African governments found the World Bank and the IMF's insistence on economic liberalization, privatization and globalization in the context of austere economic measures dissatisfying, and many were politically unhappy by the attempt of the World Bank and the IMF to minimize the role of the state as there is empirical evidence that the role of the state is important to economic growth and development. ${ }^{5}$ But in the 1980s there appeared to be no alternative to the IMF and the World Bank. Indian scholars Benu Modi and Seema Shekhawat of the University of Mumbai have commented recently on the "there is no alternative' (TINA) discourse, the IMF/World Bank being the major source of funding, that prevailed throughout the 1980s ..." (2009). ${ }^{6}$ With the West as Africa's largest financier and trading partner, options were limited in the 1980s. After the fall of the Berlin Wall and the dissolution of the Soviet Union, democracy was imposed as a political condition for World Bank loans. But the capitalist drive that had facilitated the internationalization of production and the concomitant skills and technology transfer with outsourcing in the 1980s would promote new sites of capitalist accumulation in places such as China, India and Malaysia. This is not to dismiss the active role states played in these countries in planning, financing, attracting investment and charting economic growth, though it is equally important to emphasize the conjuncture of factors that would accelerate economic growth in Asian countries such as China and India (Santos-Paulino and Wan, 2010). For China, in particular, international trade or the export sector and state-led capitalism have been the twin pillars of its remarkable economic growth, not to dismiss its huge market of 1.3 billion people. Indeed, China is the "only political economy where state-owned companies are at the cutting edge of globalization" (Henderson, 2010, p. 10). With their different history of 
relations with Africa, it followed logically when these Asian countries turned to Africa for trade and investment, the tenor of engagement would be different.

Neither Asia nor the Arabian Gulf countries are newcomers to West Africa. Saudi Arabia has been a site of pilgrimage and trade for centuries, a connection that has intensified with the advent of air travel. Investment funds from Kuwait were significant in development agendas in early independent West Africa. Some West African Muslim countries have been members of the World Islamic League (Congress), viewing their membership as a way to bring together religion, Islamic philanthropy and development. Ahmadu Bello, the Sardauna of Sokoto and premier of the Northern Nigerian regional government from 1960, was a founding member of the World Islamic League and its first vice president. China has been present in Africa from the 1960s, its early presence marked by impressive projects such as the TanZam or TAZARA railway in the 1970s, which linked the landlocked country of Zambia to the coastal country of Tanzania (Monson, 2009). China has had diplomatic ties with countries such as Ghana from the very early days of Ghana's independence, and China's vice premier Nie Rongzhen attended Ghana's independence celebrations in 1957. Japan's engagement with West Africa dates to the 1930s, a decade which witnessed an influx of Japanese cotton textiles into the region. This Japanese endeavor to enter the West African market was undermined by high British tariffs and quotas (Ampiah, 1990). The early years of independence saw a return of Japanese interest, again largely in British colonies and a desire for a Japanese-British commercial partnership which did not materialize. Thus there is a long history to recent developments such as Japan's Tokyo International Conference on African Development (TICAD) in 1993, and the Chinese Forum on China-Africa Cooperation (FOCAC) in 2000.

\section{THE AGE OF OUT-SOURCING: INTERNATIONAL PRODUCTION IN THE POST-1980S}

The internationalization of production from the 1980s, which has dispersed sites of production from North America and Europe to Asia, connected by more efficient transport and telecommunication networks, have inadvertently benefited trading networks in West Africa with small businesses coming into their own and circumventing old 
trading intermediaries such as the Lebanese (Hourani and Shehadi, 1992; Akyeampong, 2006; Beuving, 2006). Developments in shipping and air transport from the 1990s have placed Asia within the nexus of Africa's trading networks (Pedersen, 2001). These include the emergence of the Danish shipper Maersk and the French shipper Delmas as the major shipping lines connecting Europe and North America, Africa and Asia, and their creation of hub-ports in Africa and the Gulf area (Dubai's Jebel Ali port) that have tended to expand the service areas of these ports and connected Africa and the Gulf in a more organized system of transport. By the early 1990s Dubai had become a major transfer center for sea and air transport between North America/Europe and Southeast Asia (Pedersen, 2001; Fleming and Hayuth, 1994), as well as becoming a major commercial entrepot in its own right. The emergence of direct airline routes between the Gulf and West African countries by airlines such as Emirates incorporated the United Arab Emirates (UAE) into the itineraries of West African traders. Today special fares are offered to entice traders from Lagos to Dubai. Many Ghanaians fly on Emirates airline to Europe and North America, using their transit stops in Dubai to go shopping. As air freight is a by-product of air passenger transport, the emergence of these airline networks holds promise for non-traditional exports in West Africa to the Gulf, such as Ghana's export of pineapples, which depends on air freight in order to retain its freshness.

The impact of the internationalization of production has been unforeseen and profound. Take the example of the manufacture of automobile parts in China by American automobile companies. China has become proverbial for imitation, and access to new technologies through the internationalization of production informed China's domestic automobile industry. In 2001, China sent its first automobiles to the Detroit Auto Show priced modestly at under US $\$ 10,000$, and American auto analysts denigrated the quality of the Chinese cars. It was a reminder of an earlier similar development in the 1980s when South Korea had sent the first Hyundai cars to the American market. Again, the Hyundai cars were criticized for their inferior quality, but they were affordably priced at $\$ 5,000$. Today India, South Korea and China are all exporting cars to Africa, and the quality and diversity of Hyundai cars on the American market have improved considerably. As China has become the workshop of the Western world, Chinese products have flooded the African market crowding out Western manufactured goods. By 
2007 China's trade with Africa had grown in value to place third after the United States and France. The value of trade between China and Africa rose from US\$11 billion in 2000 to US\$56 billion in 2006. India's trade also witnessed phenomenal growth over the same period from US\$965 million in 1991 to US\$35 billion in 2008 (Modi and Shekhawat, 2009). Dubai may have been slotted by Maersk and Delmas as a transfer center in the sea transport networks linking Europe and North America with Southeast Asia. But these processes underpinned the emergence of Dubai's DP World as the world's largest container port operator, positioning it by the mid-2000s as a rival to major European companies; DP World successfully wrested a US\$455 million contract from the French company Bollore to expand Dakar's port in Senegal. DP World already manages port terminals in Djibouti and Mozambique, strategic points along the Red Sea and the Indian Ocean. ${ }^{7}$ HE Sheikha Lubna bint Khalid bin Sultan Al Qasimi has noted how transport and logistics has quickly become the second largest sector in the UAE's economy after oil and gas. DP World now manages some 30 ports worldwide including ports in Australia and Europe. A large airport is being established new Dubai port to combine its capacity for sea and air cargo. ${ }^{8}$

In India the information technology or software sector has been acknowledged by many as being at the forefront of India's remarkable economic growth over the past two decades, together with the government's move from a more centrally-planned socialiststyle approach to the economy to a pro-liberalization stance from 1991. India's growth rates jumped from the low average of 1.5 per cent in the 1980s to 5 per cent in the 1990s. The outsourcing of technical jobs to India is well-known, and the service sector has benefited from the IT boom (Chakraborty, 2010). Clearly, this is a reflection of India's investment in human resource development and government policies that have targeted productivity.

\section{AN ALTERNATIVE ECONOMIC PARADIGM: THE SIGNIFICANCE OF ASIAN AND ARABIAN GULF COUNTRIES IN WEST AFRICA'S CONTEMPORARY POLITICAL ECONOMY}

Though not without their problems, Asian and Arab investments in Sub-Saharan Africa represent exciting opportunities. ${ }^{9}$ I can cite three key reasons for this excitement. 
First, the situation in the 1980s when the IMF and World Bank were the only options for external loans and grants for Africa has definitely passed away. We have moved from the age of TINA ("there is no alternative") in the 1980s to TAMA ("there are many alternatives") according to the coinage of the World Social Forums. Indeed, at the Beijing summit of FOCAC in November 2006, China pledged to overtake the World Bank as the main financier of Africa. India has refined its economic engagement with Africa with the "Focus: Africa" program launched under the Export Import (EXIM) Bank in the 20022007 period, and its "Go Global Policy" aimed at boosting trade with Sub-Saharan Africa. Arab investments in Sub-Saharan Africa in the last decade have been no less spectacular, ranging from Kuwait Zain's acquisition of Celtel for US\$3.5 billion in 2005 and the acquisition of South Africa's top tourist spot, Cape Town's V \& A Waterfront by a consortium including Dubai World for almost US\$1 billion. ${ }^{10}$

Second, African countries have struggled unsuccessfully to diversify their economies from the colonial setting, and the continued centrality of Europe and North America as sources of investment, loans and grants ensured that despite well-meaning Western rhetoric that situation did not change. Albert Sarraut (1872-1962), Colonial Minister for France from 1920-24 and 1932-3 best captured the structure and intent of the colonial economy.

Economically, a colonial possession means to the home country simply a privileged market whence it will draw the raw materials it needs, dumping its own manufactures in return. Economic policy is reduced to rudimentary procedures of gathering crops and bartering them.

Moreover, by strictly imposing on its colonial "dependency" the exclusive consumption of its manufactured products, the metropolis prevents any efforts to use or manufacture local raw materials on the spot, and any contact with the rest of the world. The colony is forbidden to establish any industry, to improve itself by economic progress, to rise above the stage of producing raw materials, or to do business with the neighboring territories for its own enrichment across the customs barriers erected by the metropolitan power (Fetter, 1979, p. 109).

The colonial economy revolved around commerce, mining and agriculture. Mining was extractive and the raw material exported with little processing. In agriculture colonial governments encouraged monocrop economies. Infrastructure aimed at the extraction of resources and rail and roads connected ports to areas rich in mineral resources or 
agricultural production. Colonial infrastructure was not intended to integrate colonial economies or provide a foundation for economic growth based on internal logic.

Securing funding for infrastructural projects that would underpin economic diversification and growth has been a challenge for African countries since independence. Former colonial powers have been disinclined to provide funding for infrastructural development. Plans to establish the Volta River Project came apart in the 1950s once Ghana became self-governing and British and Canadian interests were no longer willing to put up the funding. Kwame Nkrumah, Ghana's first president, turned to the American company Kaiser, and secured funds for the hydro-electric project on terms that were economically unfavorable to Ghana. Western countries and the World Bank declined to fund the railway from Zambia to Tanzania in the 1970s, until China stepped in to build the TanZam railway with interest-free funds that it provided. In the past decade abandoned railways are becoming functional again with Chinese and Indian assistance, with Africa experiencing infrastructural growth that it has not seen since independence. The TanZam railway was built in the 1970s with the intention of transporting Zambian copper to the Tanzanian port of Dar es Salaam. By the 1990s both Zambia's copper mines and the TanZam railway were in a state of disrepair. Today defunct copper mines in Zambia such as the Chambishi Copper Mine have come back into production with Chinese funding, and China has provided US\$100 to revamp the dilapidated TanZam railway. Plans to link the rehabilitated TanZam railway to the Benguela line connecting Angola to the Atlantic, also being built by the Chinese, would create the "first-ever eastwest corridor across the continent ..." (Modi and Shekhawat, 2009). This sort of infrastructural development defies colonial logic and integrates national and regional economies in new ways. It takes a different kind of logic to appreciate the economic opportunities that lie in linking up African countries in such new ways. The giant mobile phone company Celtel's CEO, Marten Pieters, recognized the economic potential in these new linkages when he observed:

Africa's borders are colonial, they do not reflect economic or linguistic relations, so there is a lot of inter-country traffic and that is where the opportunities lie. Calls between Kinshasa and Brazzaville are still routed via Europe. We think that there is a big opportunity to build a genuinely African communications system, so we are focusing on establishing cross-border links, which is why we offer 
subscribers in Kenya, Uganda and Tanzania discount rates from normal international tariffs. ${ }^{11}$

It has taken a former colonial country like India, now a giant in information and communications technology (ICT) and a strong advocate of South-South cooperation, to launch a US\$500 million Pan-African e-network in February 2009 as part of its "Aid to Africa" program (Modi and Shekhawat, 2009).

Third, is the search for a viable economic model for Africa. By the 1970s, as we have noted above, modernization theory as the instrument for Africa's transformation had been discredited. Dependency and World Systems theorists stepped in to explain Africa's persistent under-development. As African economies plummeted in the 1980s, a decade referred to as Africa's "lost decade," even the concept of "development" seemed to have disappeared from the discourse of international agencies where Africa was concerned. The emphasis for Sub-Saharan Africa was poverty reduction not wealth creation. In the light of Africa's huge developmental challenges in so many sectors from health, education, infrastructure, telecommunication, and persistent low productivity, African countries have conceded that the state planning would have to be central to strategies of economic growth. Yet structural adjustment from the 1980s has been intent on making Sub-Saharan African economies into pale versions of Western ones with the drive to liberalize, privatize and globalize, a process that has made African economies more vulnerable to Western penetration and exploitation. The viability of South-South trade and cooperation has modified this picture as the Arab world and Asia have become serious sources of financial capital and technology. While African countries have been impressed by China's remarkable rates of growth and the improvement of the living conditions of millions of Chinese poor, the practices of Chinese companies in Africa, the influx of Chinese immigrants into African countries, cheap and shoddy Chinese goods, Chinese imitation of African products, and the adverse impact on African local industries have raised critical questions of how to engage China to minimize the negative aspects of Africa-China relations. Huge Chinese investments in Africa have been in extractive industries such as oil and mining, depletive resources that have prompted African leaders to consider seriously what their countries want in return for China's economic demands. 
Oil-rich Arab countries have followed a unique route to economic development that cannot be the norm for many Sub-Saharan African countries.

There has been strong interest in India's economic success, based on the development of human capital, information and communications technology, agriculture, small, medium and large scale manufacturing, and heavy industry. India did not become the workshop or the factory of the West like China. But its path of development has made it an important source of information technology expertise for the West, underpinning the rise of its service industries such as call centers that serve American and European markets from India. India has become a pioneer in new industries such as software technology that has made it attractive to the West, and has strengthened its traditional industries such as textile manufacture and transport. And for African countries India's combination of economic development and democracy offers a more attractive model. For Ghana, our case study of how a West African country has utilized these new economic opportunities from Asia and the Arab world, India and Malaysia have been the countries to watch and emulate. India has been a traditional ally of Ghana from the 1950s, working together in the Non-Aligned Movement. India assisted in the training of the Ghana Air Force from 1959, seconding Indian pilots and selling Ghana Indian-made aircraft (Addae, 2005). Malaysia is Ghana's contemporary in terms of the attainment of independence with a similar GDP then. The story half a century later is well known. Ghanaians remember that Malaysians came to Ghana in the 1950s to learn about oil palm production and borrowed seedlings. Today Malaysia is the world's leading producer of crude oil palm with an annual value of US\$10 billion. ${ }^{12}$

\section{GHANA: WEST AFRICA'S GATEWAY IN THE GOLDEN AGE OF BUSINESS}

Ghana's return to democracy was part of what has been described as the second wave of independence in Africa, when the fall of the Berlin Wall in 1989 triggered a wave of democratic protests across Africa leading to the birth of new democracies and the reform of old ones. In Ghana the Provisional National Defense Council (PNDC) under Flight Lieutenant J. J. Rawlings transformed itself into a political party, the National Democratic Congress (NDC), and won elections in December 1991 to form a new civilian government from 1992. In 2000 the opposition New Patriotic Party (NPP) 
won the elections and occasioned one of the few examples of a peaceful transfer of political power in Sub-Saharan Africa. Under the PNDC, Ghana had embarked on structural adjustment in 1983 under the tutelage of the IMF and the World Bank, becoming the poster country of the World Bank by the late 1980s for the supposed success of the Bank's reforms (Hutchful, 2002). Growth however sagged in the 1990s, and the World Bank then held up Uganda as its poster country.

In the 1990s the NDC government took economic liberalization down novel paths such as the passage of dual citizenship that opened up the economy to Ghanaians resident abroad. The consolidation of Ghana's political democracy and economic reform in the past two decades within the context of civil wars in Liberia, Sierra Leone and Côte d'Ivoire and political instability within the West African sub-region positioned the country as the gateway to the West Africa region. The NDC government of 1992-2000 made investment promotion trips to Asia and elsewhere, highlighting Ghana's attractiveness as a destination of foreign investment. The NPP government from 2000 built on this foundation, emphasized Ghana's unique political credentials in the West African region, hosted a "homecoming summit" to attract Ghanaians abroad to invest in the country's economic development, and declared the decade the "Golden Age of Business." The private sector was posited as the engine of growth. Under President Kufuor's leadership, the NPP government went on several business trips to North America, Europe, the Middle East and Asia and this section of the paper examines how the government positioned Ghana as an ideal site of investment and explored deepening links with the Gulf countries and Asia in the new spirit of South-South cooperation.

President Kufuor is an able salesman, and he outlined Ghana's attractiveness as a site of investment in his 2002 trip to Malaysia and India in ways that elicited the enthusiasm of business interests in both countries. First, he drew attention to the Ghana Investment Promotion Act, 1994 (Act 478) and the incentives and concessions granted to investors under this act. These include full exemption from customs duties for machinery and equipment required for the setting up of enterprises. He assured investors of the transferability of profits, dividends and royalties, and of a framework for the arbitration of investment disputes. Second, he highlighted the fact of Ghana's membership of the Economic Community of West African States (ECOWAS), and how this common market 
meant that investing in Ghana gave one access to ECOWAS' 250 million population. This is the gateway vision. Third he discussed Ghana's preferential access to markets in the European Union and the United States based on Ghana's accession to the Fourth Lome Convention (EU) and the African Growth and Opportunities Act (AGOA, US) and how Asian investors could accordingly export made-in-Ghana goods to these markets. ${ }^{13}$ This would be the golden age of business in Ghana.

The presence of a small but growing Ghanaian community in Dubai and Dubai's increasing international recognition as a financial center, tourist destination, and real estate haven encouraged Kufuor's vice president, Alhaji Aliu Mahama, to visit Dubai in an endeavor to boost bilateral ties between the two countries. In 2004 trade between Dubai and Ghana was valued at about 267 million dirhams (about US \$66 million) with the amount of Ghana's exports to Dubai standing at 46.2 million dirhams (about US $\$ 10.4$ million). But there was an even more important statistic, as we see from the figures and tables below compiled from records of the Ghana Investment Promotion Center. While the number of investment projects by the United Arab Emirates (UAE) in Ghana between 1994 and 2009 are few, six compared to 264 by Ghana's former colonial power Britain, 415 by China or 388 by India, in terms of the value of Foreign Direct Investment (FDI) the UAE ranked third (US\$2.06 billion) only after Britain (US\$4.83 billion) and the United States (US\$2.46 billion). ${ }^{14}$ Equally important, the UAE investments were largely in building and construction, an important sector of Ghana's economy. [FIGURES 1 AND 2 AND TABLES 1 AND 2 INSERTED HERE] 


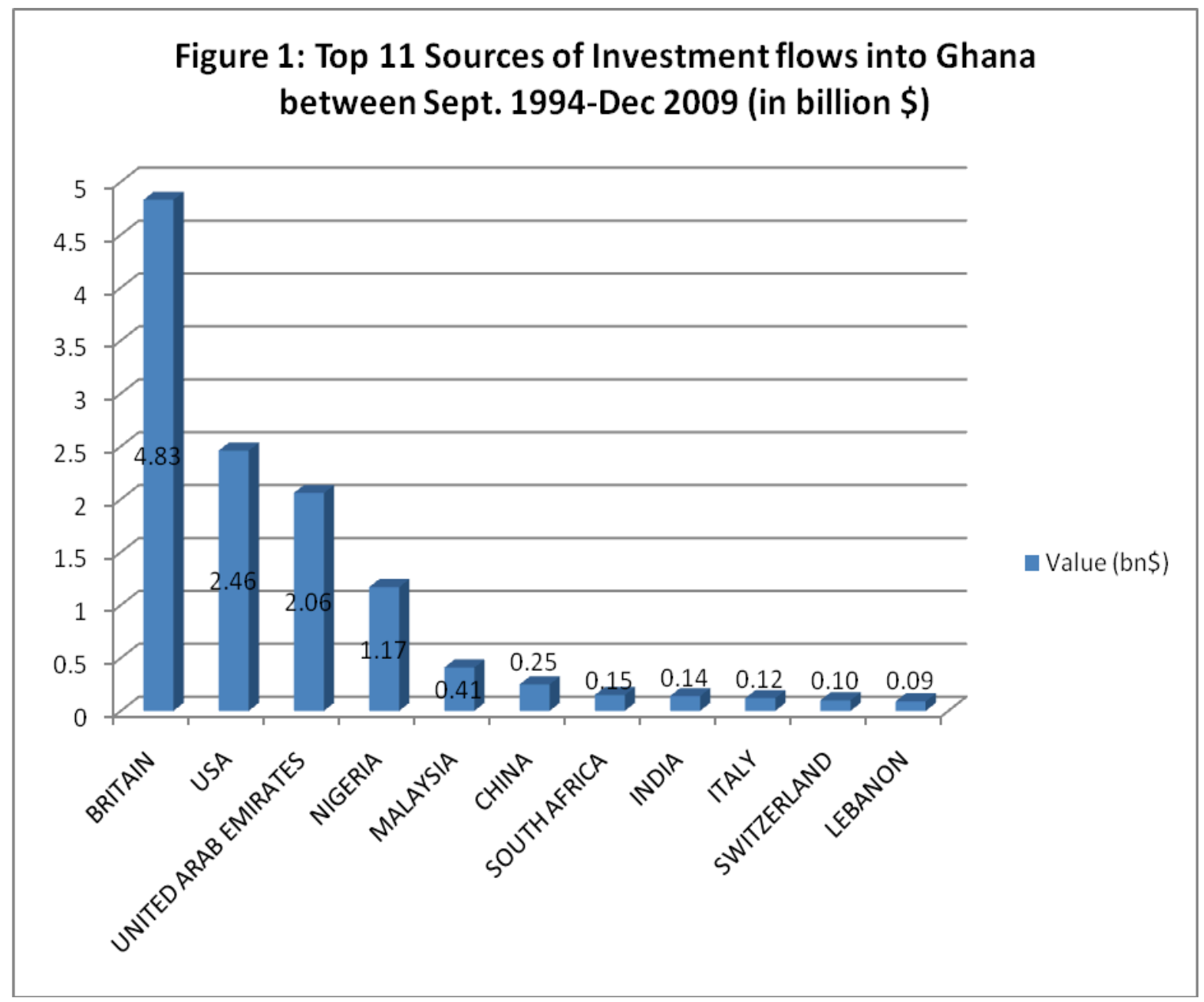

Source: Computed by Author from Ghana Investment Promotion Centre Dataset 


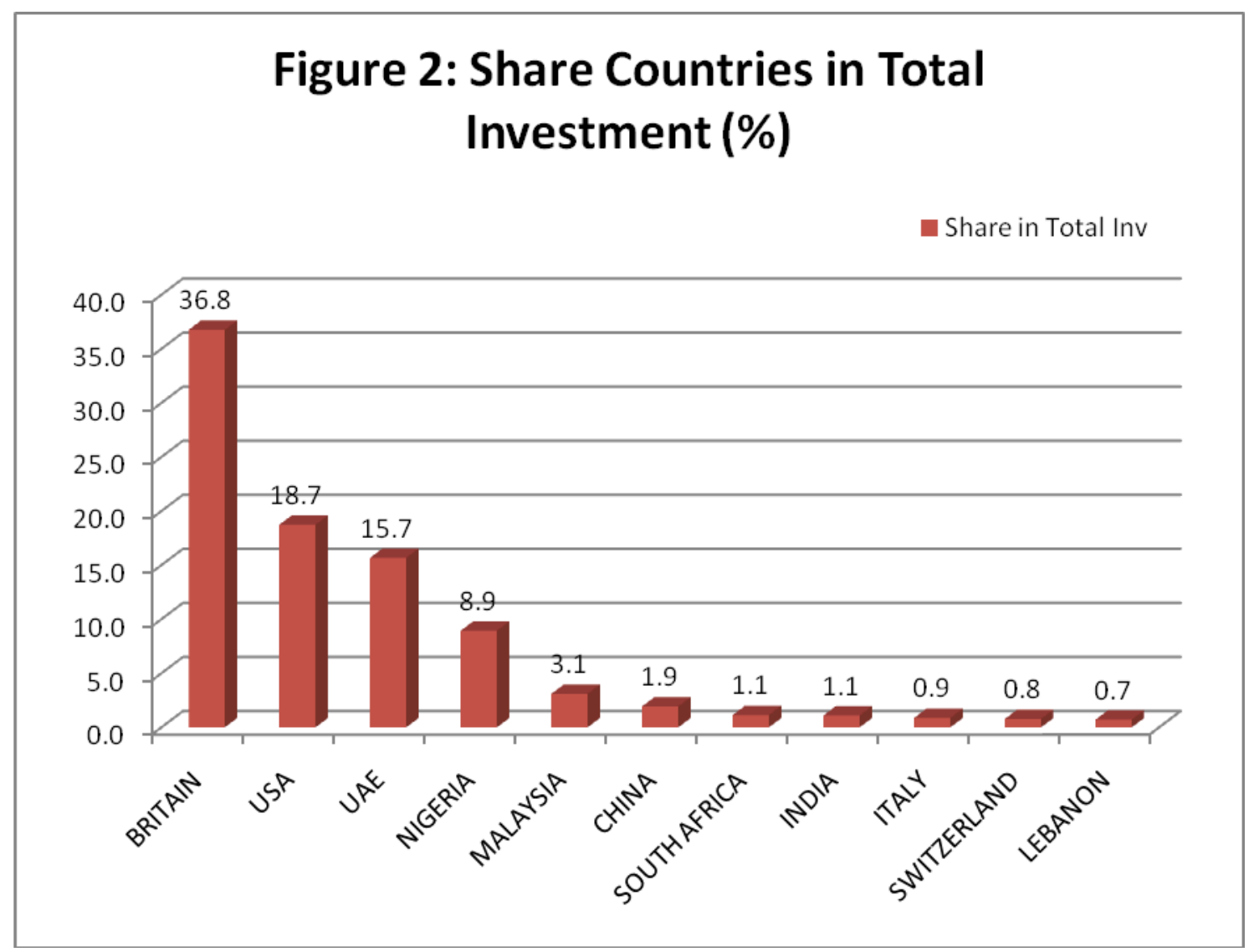

Source: Computed by Author from Ghana Investment Promotion Centre Dataset

Table 1: Four Main Sectors of Investment by the Top 11 Countries 1994 - 2009

\begin{tabular}{|l|c|c|c|c|}
\hline \multicolumn{1}{|c|}{ Country } & 1st & 2nd & $\mathbf{3}^{\text {rd }}$ & 4th \\
\hline BRITAIN & $\begin{array}{c}\text { Manufacturing } \\
(96.6 \%)\end{array}$ & $\begin{array}{c}\text { Build \& Const } \\
(1.6 \%)\end{array}$ & $\begin{array}{c}\text { Service } \\
(1.3 \%)\end{array}$ & $\begin{array}{c}\text { General Trade } \\
(0.3 \%)\end{array}$ \\
\hline USA & $\begin{array}{c}\text { Manufacturing } \\
(90.4 \%)\end{array}$ & $\begin{array}{c}\text { Service } \\
(5.6 \%)\end{array}$ & $\begin{array}{c}\text { Agriculture } \\
(2.0 \%)\end{array}$ & $\begin{array}{c}\text { Building \& } \\
\text { Construction } \\
(1.1 \%)\end{array}$ \\
\hline UAE & $\begin{array}{c}\text { Building \& } \\
\text { Construction } \\
(99.9 \%)\end{array}$ & $\begin{array}{c}\text { Service } \\
(0.05 \%)\end{array}$ & $\begin{array}{c}\text { General Trade } \\
(0.02 \%)\end{array}$ & - \\
\hline NIGERIA & $\begin{array}{c}\text { General Trade } \\
(67.8 \%)\end{array}$ & $\begin{array}{c}\text { Service } \\
(29.9 \%)\end{array}$ & $\begin{array}{c}\text { Building \& } \\
\text { Construction } \\
(1.3 \%)\end{array}$ & $\begin{array}{c}\text { Manufacturing } \\
(0.7 \%)\end{array}$ \\
\hline MALAYSIA & $\begin{array}{c}\text { Service } \\
(98.6 \%)\end{array}$ & $\begin{array}{c}\text { Manufacturing } \\
(1.1 \%)\end{array}$ & $\begin{array}{c}\text { General Trade } \\
(0.15 \%)\end{array}$ & $\begin{array}{c}\text { Building \& } \\
\text { Construction } \\
(0.07 \%)\end{array}$ \\
\hline CHINA & $\begin{array}{c}\text { Manufacturing } \\
(64.7 \%)\end{array}$ & $\begin{array}{c}\text { General Trade } \\
(21.0 \%)\end{array}$ & $\begin{array}{c}\text { Service } \\
(6.5 \%)\end{array}$ & $\begin{array}{c}\text { Building \& } \\
\text { Construction }\end{array}$ \\
\hline
\end{tabular}




\begin{tabular}{|l|c|c|c|c|}
\hline & & & & $(2.9 \%)$ \\
\hline SOUTH & Agriculture & Service & General Trade & Manufacturing \\
AFRICA & $(61.2 \%)$ & $(28.3 \%)$ & $(6.1 \%)$ & $(2.0 \%)$ \\
\hline INDIA & Agriculture & General Trade & Manufacturing & Service \\
& $(32.5 \%)$ & $(24.2 \%)$ & $(20.0 \%)$ & $(11.1 \%)$ \\
\hline ITALY & Manufacturing & Building \& & Tourism & Export Trade \\
& $(62.5 \%)$ & Construction & $(2.0 \%)$ & $(1.1 \%)$ \\
& & $(32.3 \%)$ & & \\
\hline SWITZERLAND & Agriculture & Manufacturing & Service & Tourism \\
& $(45.2 \%)$ & $(25.4 \%)$ & $(16.0 \%)$ & $(4.1 \%)$ \\
\hline LEBANON & General Trade & Manufacturing & Build \& Const & Tourism \\
& $(50.2 \%)$ & $(27.9 \%)$ & $(11.0 \%)$ & $(6.4 \%)$ \\
\hline
\end{tabular}

Source: Computed from Dataset of Ghana Investment Promotion Centre (GIPC)

Table 2: Leading Countries in Sectoral Investment in Ghana Sept 1994 - Dec 2009

\begin{tabular}{|l|c|c|c|c|}
\hline \multicolumn{1}{|c|}{ Sectors } & 1st & 2nd & 3rd & 4th \\
\hline Agriculture & $\begin{array}{c}\text { South Africa } \\
(29.0 \%)\end{array}$ & $\begin{array}{c}\text { France } \\
(15.9 \%)\end{array}$ & $\begin{array}{c}\text { USA } \\
(15.3 \%)\end{array}$ & $\begin{array}{c}\text { India } \\
(14.8 \%)\end{array}$ \\
\hline $\begin{array}{l}\text { Building \& } \\
\text { construction }\end{array}$ & UAE & Britain & Italy & Sierra \\
& $(91.0 \%)$ & $(3.4 \%)$ & $(1.65 \%)$ & $\begin{array}{c}\text { Leone/Lebanon } \\
(1.61 \%)\end{array}$ \\
\hline Export Trade & India & Switzerland & Netherland & Britain \\
& $(39.1 \%)$ & $(17.7 \%)$ & $(16.3 \%)$ & $(10.5 \%)$ \\
\hline General Trade & Nigeria & China & Lebanon & India \\
& $(90.0 \%)$ & $(5.4 \%)$ & $(4.8 \%)$ & $(3.6 \%)$ \\
\hline Liaison & France & USA & Switzerland & Germany \\
& $(67.5 \%)$ & $(24.3 \%)$ & $(6.9 \%)$ & $(4.0 \%)$ \\
\hline Manufacturing & Britain & USA & China & Italy \\
& $(64.3 \%)$ & $(30.7 \%)$ & $(2.3 \%)$ & $(0.99 \%)$ \\
\hline Service & Malaysia & Nigeria & USA & Ireland \\
& $(32.8 \%)$ & $(28.6 \%)$ & $(11.3 \%)$ & \\
\hline Tourism & British Virgin & USA & China & Lebanon \\
& Islands & $(11.4 \%)$ & $(4.8 \%)$ & $(4.4 \%)$ \\
& $(32.8 \%)$ & & & \\
\hline
\end{tabular}

Source: Computed from Dataset of Ghana Investment Promotion Centre (GIPC)

The Kufuor government seemed to privilege investments in infrastructure, telecommunications, ICT, and education or skills training, having concluded that growth in these areas would create an enabling investment environment. Roads, rail, power generation, water supply, port facilities, irrigation, capacity building and some prestige 
projects that transformed the cityscape of the capital were the hallmarks of the Kufuor administration. And this is where Asian and Arab investment was instrumental. Asian and Arab countries were approached for investments and partnerships in areas of their strength, but their diversity also prevented Ghana's undue dependence on any single country. For road and rail construction and rehabilitation the government of Ghana turned to China and India. In April 2003 Ghanaian newspapers quoted a report by the Minister of Ports, Harbors and Railways that a number of Indian and Chinese investors had expressed interest in assisting to revamp the country's railway. ${ }^{15}$ Both countries have impressive rail systems, and India is reported to have the largest rail network in Asia and the world's second largest under one management. The Delhi Metro has attracted national and international attention. ${ }^{16}$ In April 2005 China pledged to assist Ghana with the rehabilitation of its rail system, and in December of that year an eleven-member team of railway experts arrived from China to conduct a feasibility study on the rehabilitation and expansion works on the eastern rail lines projected at the cost of US\$2 million and to be funded by the Chinese government. ${ }^{17}$ Reflecting the UAE's growing recognition in transport development, the Ghana Railways Company Ltd in 2008 entered into a concessionary agreement with KAMPAC M. E. of UAE to build, operate and transfer the Western and Central Railway lines after 35 years. ${ }^{18}$

Ghana has three main international roads radiating north, west and east from the coastal capital of Accra: the first is the northern road through Kumasi onwards to Burkina Faso; the second from Accra through Cape Coast to Elubo and Côte d'Ivoire (western artery); and the third runs east from Accra through Aflao in the Volta Region to Togo (eastern artery). These roads have received constant attention over the past several years, and the Kufuor government committed itself to transforming them into dual carriage roads. The western artery has been reconstructed. The Kufuor government approached the Chinese government for assistance and in 2002 China agreed to provide financial support for the construction of 17.6 kilometer two-way lane and 40.5 kilometer dual carriage portions of the Accra-Kumasi road within three years. ${ }^{19}$ In June 2006 The Chinese Prime Minister joined President Kufuor to open the US\$29 million stretch of highway leading from out of Accra to Kumasi. ${ }^{20}$ 
In terms of water and electricity supply, two key services central to industrial production and manufacturing and for which the Accra-Tema metropolitan area has had irregular supply, the Kufuor government approached Ghana's development partners for assistance. One of the countries first approached was Kuwait in 2002 and the Kuwaiti government, per the Kuwait Fund for Arab Economic Development, committed US\$16.2 million to enable the government of Ghana undertake a major power project. The Daily Graphic reported that:

The project involves the construction of 215 kilometre transmission lines to evacuate power from the Aboadze Thermal Plant in Takoradi to the Volta River Authority (VRA) sub-station in Tema. The estimated cost of the project stands at US\$22 million and the VRA which is the implementing agency is expected to provide the remaining amount to be raised from its own resources. ${ }^{21}$

The Chinese government also agreed to strengthen Ghana's capacity to supply water and electricity. In 2006 it pledged to build a new plant at Kpong to increase water supply to the eastern parts of Accra by 40 million gallons a day. ${ }^{22}$ In 2009 the Chinese government provided the Electricity Corporation of Ghana with US\$170 million supplier's credit for the extension of electricity to 300,000 households. $^{23}$

The largest Chinese (infrastructural) project embarked upon in Ghana thus far has been the construction of the Bui Hydro-electric Dam in the northern part of Ghana. In October 2005 the Daily Graphic reported that the government of Ghana and Sino-Hydro, a Chinese construction firm, had signed a Memorandum of Understanding (MOU) to undertake the construction of the Bui Dam. ${ }^{24}$ Financed by the Chinese Export-Import Bank (EXIM Bank), the project will cost an estimated US\$600 million of which the Ghana government will contribute US\$60 million. Envisaged as an integrated development project, the new dam will supply about ten per cent of the country's current energy needs, include an irrigation component that will irrigate about 30,000 hectares of land, and serve as a major tourist site. ${ }^{25}$

The Kufuor government has turned to India and China for assistance also in the spheres of telecommunications and ICT. In 1995, under the NDC government, Telekom Malaysia had acquired a 30 per cent stake in the state-owned Ghana Telecom at US\$30 million. Telekom Malaysia was dismayed by the Kufuor government's apparent preference to work with China in the field of telecommunications and disapproved when 
the government of Ghana signed a US\$150 million loan agreement with Alcatel Shanghai Bell of China to supply Alcatel products in the government's planned expansion scheme. Telekom Malaysia sought to offload its share in Ghana Telecom to the Ghana government, but its asking price was five times what it had paid to acquire the shares just a few years earlier. The resulting dispute ended at the international court at The Hague in 2002 and an amicable settlement was reached in $2005 .^{26}$

India has been Ghana's natural partner in ICT. In computer software India is one of the world's major exporting nations with a surplus of computer scientists. Software engineering, web-based services, E-commerce solutions, and Business Process Outsourcing (BPO) have become key components of the Indian economy. It is not surprising that 100 of the Fortune 500 companies have established research and development outfits in India. ${ }^{27}$ In 2002 the Governments of Ghana and India committed to establishing an ICT Center of Excellence in Accra to serve Ghana and the West African sub-region. And land was acquired near the state house. The Ghana government is being assisted in this endeavor by the Bangalore Information Technology Park in India, which serves as a model, and the completed project will be a source of ICT facilities for corporate bodies, businesses and individuals. Estimated to cost US\$4 million, the government of Ghana is financing the construction of the center at US\$2 million, while the government of India is providing technical know-how and ICT equipment at the cost of US\$2 million. ${ }^{28}$ A further boon to Ghana's digital plans was reported by the Daily Graphic in February 2007 that the Ghana government had obtained a loan of US $\$ 30$ million from China for the construction of a national fiber optic communication backbone to enhance ICT.

India and China have both been assisting Ghana in technical training and capacity building, and both provide several scholarship slots a year for Ghanaian professions to train in India and China. In this endeavor, India has been a more attractive option, offering Ghanaians a more diverse array of specialties based on India's development of small- and medium-scale industry and appropriate technology. Thus between 2000 and 2005, 300 Ghanaians went to India to study in the fields of IT, biotechnology, food processing, water resources development, tool designing, entrepreneurship development, small business creation, income generating activities for women entrepreneurs, and rural 
industry promotion. ${ }^{29}$ In 2006 India awarded Ghana 70 out of a total of 800 training slots assigned for Africa under the Indian Technical and Economic Co-operation (ITEC) program. ${ }^{30}$

Ghana's strategic investment in infrastructure together with its growing international recognition as a stable country politically with sound economic policies seems to be paying off. In 2009 the Africa campus of the China-Europe international business school (CEIBS) was established in Accra. Ghana's development partners like China have also pledged their support in Ghana's bid to become a middle-income country. The cityscape in Accra and other regional capitals is fast changing reflecting Ghana's attractiveness as a site of international investment. Richard Grant in his recent study of Accra as a globalizing city noted how there are now three Central Business Districts (CBDs) in Accra: the old CBD from the colonial period in Ussher Town with older European and Ghanaian companies; a national CBD in central Accra with many of the national corporations; and a global CBD along the Osu-Cantonments-Airport axis where most of the new foreign companies operate. The proliferation of real estate companies building middle-class homes and gated communities for expatriates and Ghanaians resident abroad have all added to the changing cityscape (Grant, 2009, p. 38). Public prestige projects such as the National Theater in Accra built with Chinese funds, ${ }^{31}$ the rehabilitation of the presidential lodge in Peduase again with Chinese funds, ${ }^{32}$ and the construction of a brand new seat of government and presidential complex in Accra with financial assistance from the government of India and by an Indian company have added to Accra's reputation as a globalizing city. ${ }^{33}$ The Chinese government provided the funds that enabled a Chinese construction company renovate the stadia in Accra and Kumasi and build new stadia in Takoradi and Tamale for the Africa Cup of Nations soccer tournament hosted in Ghana in 2007.

Arab countries have been important partners in the tourist and hotel industry, and have thus contributed to the transformation of cityscapes. The Ghana Libya Arab Holding Company (GLAHCO) which owns and operates Golden Tulip Hotel in Accra, recently awarded a contract to the China State Hualong Construction Company to rehabilitate City Hotel in Kumasi at the cost of US\$14.7 million. The four-star City Hotel with its 120 rooms is now open for business. Prince Alwaleed bin Talal Abdul Aziz al-Saud of Saudi 
Arabia, has entered a joint venture with the Ghana government to rehabilitate the now defunct Ambassador Hotel at the cost of more than US\$100 million. The new hotel will be known as the Movenpick Ambassador Hotel and it will be operated by Movenpick Hotel and Resort. ${ }^{34}$ Otherwise Arab presence has largely been through the traditional avenues of official development assistance (ODA) in areas such as the building of schools and hospitals and philanthropy (emergency aid in times of crisis, the building of mosques, etc), and not through private investment (FDI). ${ }^{35}$ There is growing evidence of the recruitment of Ghanaian artisans and professionals to Arabian Gulf countries; Qatar in 2006 had an agency in Ghana for the recruitment of Ghanaian artisans, and Dubai operated a recruitment agency in Ghana for nurses. ${ }^{36}$

The discovery of offshore oil in Ghana in commercial quantities in 2007 would perhaps transform Arab engagement with Ghana and involve them more centrally in Ghana's economy, especially investments in the area of oil and gas. ${ }^{37}$ Prior to 2007, discussions or agreements between Ghana and oil-rich Arab countries had to do with sourcing oil for Ghana or building storage facilities for Ghana's oil. The visit of the Vice President Aliu Mahama to Qatar to May 2004 was in pursuit of these goals. ${ }^{38}$ The year 2005 was busy in terms of the construction of oil storage facilities. A new oil refinery that was to be built in Takoradi in 2005 was reportedly going to be serviced with oil from Saudi Arabia. ${ }^{39}$ Again in 2005 Kampac Oil, an oil company based in UAE, signed a MOU to operate an offshore storage facility in Ghana. ${ }^{40}$ That same year a group of Iranian companies concluded arrangements with the government of Ghana to establish an oil refinery in the country. ${ }^{41}$ Ghana's oil discovery has also generated a change in the nature of investments from Ghana's development partners. One study noted that in spite of China's new prominence in the Ghanaian economy, the level of its FDI remained minimal between 2001 and 2006: US\$3.13 million in 2002, US\$2.17 million in 2003; US3.09 million in 2004, and US\$17.87 million in 2005. Even in 2005, which realized the highest level of Chinese FDI, this accounted for only 8.85 per cent of total investments in Ghana. The study also noted a shift in the nature of Chinese engagement from manufacturing and agriculture in 2001 to general trade by the end of the period of study, a trend it considered non-beneficial to the Ghanaian economy (Tsikata, Fenny and Aryeetey, 2008). China, the second largest consumer of oil in the world after the United 
States, is now acting more proactively in terms of investing in Ghana's oil industry. In 2009 the China National Offshore Oil Company (CNOOC) expressed a desire to partner the Ghana National Petroleum Corporation (GNPC) to strengthen its capacity and operations in oil and gas. ${ }^{42}$ The China Development Bank has entered into a strategic partnership with GNPC and the Ministry of Finance and Economic Planning for the financing of projects in oil and gas, education, health, road infrastructure, and agriculture. ${ }^{43}$ Ghana's oil may instructively serve as the carrot for other infrastructural investments. Not to be outdone, India, a competitor for Ghana's oil, has also entered into talks with GNPC in 2009 for acquiring stakes in hydrocarbon blocks in Ghana. (Jiang and Jing, 2010). ${ }^{44}$ The coming years will determine whether Ghana will be able to spread investments across a broad array of industries in spite of its oil wealth or if the country will succumb to the Dutch Disease.

\section{CONCLUSION}

In the past decade there have been radical shifts in Ghana's political economy. In 2004 India became the leading source of FDI for Ghana followed by China (Tsikata, Fenny and Aryeetey, 2009). By 2008 China had become the major source of Ghana's imports and between 2000 and 2008 the value of Ghana's imports from China grew from US\$93 million to US\$1.5 billion (Jiang and Jing, 2010). Arab countries, especially those from the Gulf region, have become significant development partners and investors in Ghana. I have sought in this paper to examine the context for these changes, the implications for West Africa's political economy, and how a savvy Ghanaian government in the past decade positioned itself to take advantage of these new economic opportunities to transform Ghana's infrastructural base and position the country for a take-off that would catapult it to middle income status. The potential to deepen these transformations and to integrate Africa's economy more meaningfully with Asia and the Arab world is immense. Ghana has presented itself in the past decade not as an individual country seeking investments but as a gateway to the West African market.

How successful was the Kufuor government in making 2000-2008 the "golden age of business" where the private sector is concerned, and Ghana as a "gateway to West Africa"? We have referenced Ghana's remarkable growth rates under the Kufuor 
government. But the administration also received high levels of foreign aid and loans, making it hard to distinguish the internal from the external drivers of economic growth. Yaw Adu-Asare in a lengthy review of the weak Ghanaian private sector in 2004 and an economy noted for low productivity concluded that the state - and not the private sector - would have to play the leading role in the Ghanaian economy, as in other developing countries. ${ }^{45}$ The government was dogged by persistent accusations of corruption and the solid macroeconomic indicators that won it international approval declined getting to the end of Kufuor's administration. The fiscal deficit rose from 9.2 per cent of GDP in 2007 to 14.9 per cent in 2008 , the year of the elections the NPP lost, and inflation rose from 12.7 per cent at the end of 2007 to 19.9 per cent in January 2009. There had been frequent increases in fuel price, a reflection of record global prices for oil. But this resulted in high transport costs and food prices, especially for urban residents already exasperated with intermittent electricity and water supply. The jostling of over 17 leading politicians of the NPP to succeed Kufuor as the presidential candidate accompanied by the very visible splashing of money turned many off. Outside the Ashanti and Eastern Regions, its two strongholds, the NPP as the incumbent party performed poorly in the 2008 elections in urban centers, and in the three northern regions where poverty had deepened. ${ }^{46}$

Did Ghana's trade within the ECOWAS region increase under the Kufuor government, as he explicitly flagged Ghana as the gateway to West Africa? Regional integration, the prime objective of ECOWAS has been an uphill struggle since its formation in 1975 (Hanink and Owusu, 1998). The francophone countries, the majority in the bloc, their common currency (the CFA franc) and their close orientation to France posed a challenge to the development of a common market. Ironically, it has been the World Bank's SAPs that have prompted several countries since the 1980s to unilaterally lower trade tariffs and resolve other impediments to free trade. France has pushed its former African colonies in financial difficulties towards the World Bank and the IMF from the 1990s, looking to unload the financial burden of underwriting African economies. Intra-ECOWAS trade remained a minimal 11 per cent between 1996 and 2001, while over 40 per cent of ECOWAS imports for the same period came from the European Union (Alaba, 2006). Poor transport infrastructure, bad communications and 
undependable power supply, among other factors, make the cost of doing business and moving goods in West Africa high.

Ironically relief may come from the changing relations between the EU and the regional blocs within the African Caribbean and Pacific (ACP) countries, as the EU moves from the non-reciprocal trade concessions given to West African countries in the Yaounde and Lome I-IV Conventions to a series of reciprocal economic partnership agreements with West Africa from 2008. These will be structured as free trade agreements, and they will provide an incentive and most probably financial assistance for the infrastructure and telecommunication initiatives proposed by ECOWAS (Alaba, 2006). ${ }^{47}$ This is where the investment opportunities presented by Asia and the Arabian Gulf countries can be leveraged to good effect. Hitherto, African countries have dealt individually with emerging giants like China, where it would make economic sense to incorporate the opportunities China represents into ongoing plans for regional integration. Chinese assistance in infrastructural development would be instrumental. In May 2006 a delegation from the Iranian Chamber of Commerce and Industry visited Ghana to explore the possibility of establishing a strong transport network to facilitate trade between West African countries and Iran. ${ }^{48}$ Such initiatives that strengthen regional integration are to be welcomed.

The Kufuor's government trade and investment policies were in the right direction. That the government created a Ministry for Private Sector Development underscored its awareness that the private sector needed nurturing. Its emphasis on infrastructure, telecommunication, power generation, education and skills training were economically sound and aimed at making Ghana an attractive site of investment because of a skilled labor force and a lowered cost of doing business. While Ghana definitely emerged as a shining star in West Africa, the obstacles to intra-West African trade were beyond any single country. The 2008 elections should be seen, perhaps, as an indictment of complacency and corruption than bad economic policy. The Ghana Poverty Reduction Strategy I and II, which aim at making the country a middle-income country by 2015 , have indeed survived the Kufuor government.

\footnotetext{
${ }^{1}$ Ghana Investment Promotion Center advises and monitors investment in sectors except in oil, mining and the free zones.
} 
${ }^{2}$ Perhaps the most prominent advocate of what became "modernization" theory was the American W. W. Rostow (1960), a staunch advocate of capitalism and free enterprise as the bulwark against communism in developing countries.

${ }^{3}$ A classic in the dependency works on Africa is Walter Rodney (1972). Indeed, Rodney and Joseph Inikori (1992) push Africa's underdevelopment further back to the era of the export slave trade.

${ }^{4}$ Monga (2006) provides a thoughtful critique of SAPs, noting the economic soundness of several of its principles, but suggesting among other things the need to factor in unique country circumstances, and querying the sequencing of the measures applied.

${ }^{5}$ The large responsibilities assumed by states in the developed West in the recent (2008) and ongoing financial recession, speaks to the crucial role of the state in economics. The World Bank's position in Africa at the beginning of the 1990s was largely a response to corrupt and patrimonial states that had generated academic studies with titles such as Jean-Francois Bayart, The State in Africa: The Politics of the Belly (1993 ); and Patrick Chabal and Jean-Pascal Daloz, Africa Works: Disorder as Political Instrument (1999).

${ }^{6}$ Benu Modi and Seema Shekhawat, "China and India in Africa." Pambazuka News, Issue 456, November 5, 2009. Accessed on March 8, 2010 at: http://pambuzuka.org/en/category/africa_china/60030.

${ }^{7}$ Reuters, "Factbox - Recent arab Investments in Sub-Saharan Africa," March 9, 2008. Accessed March 8, 2010 at www.reuters.com/article/idUSL0766353720080310.

${ }^{8}$ Opening address by HE Sheikha Lubna bint Khalid bin Sultan Al Qasimi, Minister for Foreign Trade (the United Arab Emirates), “Africa and the Indian Ocean’ Conference, Abu Dhabi, March 14, 2010.

${ }^{9}$ For an evaluation of China's presence in Africa, for example, see Alden (2007). Criticisms of China include the use of Chinese labor for contracts in Africa; China's policy of non-interference in African politics, even in the face of blatant human rights abuses; China's focus on extractive industries and the environmental implications; and the flooding of African markets with cheap Chinese products and the adverse impact on local industries.

${ }^{10}$ Reuters, "Factbox."

11 "Africa attracts Arab Investment." Http://www.africa-business.com/features/arab africa trade.html. Accessed March 8, 2010;

${ }^{12}$ Kojo Sam, "President Kufuor's Visits to Malaysia and India." Daily Graphic, August 21, 2002.

${ }^{13}$ Sam, "Kufuor's visits to Malaysia and India." Daily Graphic, August 21, 2002.

${ }^{14}$ Registered Country Investments Classified by Sectors, Sept. 1994-Dec. 2009. Ghana Investment Promotion Center (GIPC). I am grateful to Augustine A. Otoo, Director for Investor Services, for this information.

${ }^{15}$ Daily Graphic, April 11, 2003.

${ }^{16}$ Daily Graphic, August 15, 2005.

${ }^{17}$ Daily Graphic, April 25, 2005 and December 9, 2005.

${ }^{18}$ Daily Graphic, January 24, 2008.

${ }^{19}$ Chronicle, June 19, 2002.

${ }^{20}$ Chronicle, June 20. 2006.

${ }^{21}$ Daily Graphic, October 19, 2002.

${ }^{22}$ Daily Graphic, January 6, 2006.

${ }^{23}$ Daily Graphic, October 17, 2009.

${ }^{24}$ Daily Graphic, October 28, 2005.

${ }^{25}$ Daily Graphic, August 7, 2006. April 20, 2007, and September 26, 2007.

${ }^{26}$ Daily Graphic, May 10, 2005.

${ }^{27}$ Daily Graphic, August 15, 2005.

${ }^{28}$ Daily Graphic, August 21, 2002 and December 14, 2002.

${ }^{29}$ Daily Graphic, August 15, 2005.

${ }^{30}$ Chronicle, December 15, 2006.

${ }^{31}$ The Chinese government subsequently wrote off the cost of building the national theater, considering it a gift to the people of Ghana (Daily Graphic, May 1, 2007).

${ }_{32}^{32}$ Daily Graphic, August 31, 2005.

${ }^{33}$ Daily Graphic, January 1, 2007.

${ }^{34}$ Daily Graphic, April 30, 2003 and June 4, 2005. 
${ }^{35}$ See for examples, Daily Graphic, June 8, 2005, Saudi gift for the construction of two mosques in Accra; and The Ghanaian Chronicle, August 1, 2001, Saudi assistance to flood victims in Accra.

${ }^{36}$ Daily Graphic, November18 and 22, 2006;

Http://www.ghanaweb.com/GhanaHomePage/diaspora/artikel.php?ID=152586; and

http://www.ameinfo.com/75846.html

${ }^{37}$ Ghana's oil find will reportedly generate US $\$ 1.2$ billion in annual state revenues for about two decades.

The Economist, December 31, 2009.

${ }^{38}$ Daily Graphic, May 21, 2004.

${ }^{39}$ Daily Graphic, April 1, 2005.

${ }^{40}$ Daily Graphic, August 16, 2005.

${ }^{41}$ Daily Graphic, December 12, 2005.

${ }^{42}$ Daily Graphic, September 21, 2009.

${ }^{43}$ Daily Graphic, December 10, 2009.

${ }^{44}$ Wenran Jiang and Jing Jing, "Deepening Chinese Stakes in West Africa: the Case of Ghana," China

Brief, 10:4 (2010). Accessed on March 7, 2010 at http://www.jamestown.org/programs/chinabrief.

${ }^{45}$ Yaw Adu-Asare, "Kufuor Administration's Decision to Rely on Private Sector for Development is Imprudent." Http://www.modernghana.com/news/115578/1. Accessed January 9, 2011.

${ }^{46}$ For a review of the 2008 election, see Whitfield (2008).

${ }^{47}$ Ibid.

${ }^{48}$ Daily Graphic, May 19, 2006.

\section{REFERENCES}

Addae, S. (2005), A Short History of the Ghana Armed Forces. Accra: Graphic Packaging Ltd.

Akyeampong, Emmanuel (2006), "Race, Identity and Citizenship in Black Africa: the Case of the Lebanese in Ghana", Africa, 76, 3, 297-323.

Alaba, Olumuyiwa B. (2006), EU-ECOWAS EPA: Regional Integration, Trade Facilitation and Development in West Africa. Paper presented at the GTAP Conference, UNECA, Addis Ababa.

Alden, Chris (2007), China in Africa. London: Zed Books.

Alpers, Edward (2009), East Africa and the Indian Ocean. Princeton: Markus Wiener Publishers.

Ampiah, Kweku (1990), "British Commercial Policies against Japanese Expansionism in East and West Africa, 1932-35", International Journal of African Historical Studies 23, 4, 619-41.

Austen, Ralph (1987), African Economic History. London: James Currey.

Bayart, Jean-Francois (1993), The State in Africa: The Politics of the Belly. New York: Longman.

Beuving, Joost J. (2006), "Lebanese Traders in Cotonou: A Socio-Cultural Analysis of Economic Mobility and Capital Accumulation”, Africa, 76, 3, 324-51.

Chabal, Patrick and Jean-Pascal Daloz (1999), Africa Works: Disorder as Political Instrument. Oxford: James Currey.

Chakraborty, Suparna (2010), India's Economic Growth: Lessons for the Emerging Economies, in: Santos-Paulino, Amelia U. and Guanghua Wam, eds., The Rise of China and India: Impacts, Prospects and Implications (Palgrave Macmillan).

Fetter, Bruce (1979), ed., Colonial Rule in Africa: Readings from Primary Sources. Madison: University of Wisconsin Press.

Fleming, D. K. and Y. Hayuth (1994), "Spatial Characteristics of Transportation Hubs: 
Centrality and Immediacy", Journal of Transport Geography 2, 3-18.

Grant, Richard (2009), Globalizing City: The Urban and Economic Transformation of Accra, Ghana. Syracuse: Syracuse University Press.

Hanink, Dean M. and J. Henry Owusu (1998), "Has ECOWAS promoted Trade among its Members", Journal of African Economies 7, 3, 363-83.

Henderson, Jeffrey (2010), Globalization and the Developing World: The Difference that China Makes, in: Santos-Paulino, Amelia U. and Guanghua Wam, eds., The Rise of China and India: Impacts, Prospects and Implications (Palgrave Macmillan).

Hopkins, A. G. (1973), An Economic History of West Africa. London: Longman.

Hourani, Albert and Nadim Shehadi (1992), eds., The Lebanese in the World: A Century of Emigration. London: Centre for Lebanese Studies.

Hutchful, Eboe (2002), Ghana's Adjustment Experience: The Paradox of Reform. Oxford: James Currey.

Inikori, Joseph (1992), The Chaining of a Continent. Mona: University of the West Indies.

Manning, Patrick (1998), Francophone Sub-Saharan Africa: 1880-1995. Cambridge: Cambridge University Press.

Meagher, Kate (2003), “A Back Door to Globalisation? Structural Adjustment, Globalisation and Transborder Trade in West Africa", Review of African Political Economy 30, 95, 57-75.

Middleton, John (1992), The World of the Swahili: An African Mercantile Civilization. New Haven: Yale University Press.

Monga, Celestin (2006), Commodities, Mercedes-Benz and Structural Adjustment: An Episode in West African History, in: Emmanuel Kwaku Akyeampong, ed., Themes in West Africa's History (James Currey).

Monson, Jamie (2009), Africa's Freedom Railway: How a Chinese Development Project Changed Lives and Livelihoods in Tanzania. Bloomington: Indiana University Press.

Pearson, Michael (1998), Port Cities and Intruders: The Swahili Coast, India and Portugal in the Early Modern Era. Baltimore: The Johns Hopkins University Press.

Pedersen, Paul O. (2001), "Freight Transport under Globalization and its Impact on Africa", Journal of Transport Geography 9, 85-99.

Rimmer, Douglas (2003), "Learning about Economic Development from Africa", African Affairs 102, 469-91.

Rodney, Walter (1972), How Europe underdeveloped Africa. London: BogleL'Ouverture Publications.

Rostow, W. W. (1960), The Stages of Economic Growth: A Non-Communist Manifesto. Cambridge: Cambridge University Press.

Santos-Paulino, Amelia U. and Guanghua Wam (2010), eds., The Rise of China and India: Impacts, Prospects and Implications. New York: Palgrave Macmillan.

Tsikata, Dela, Ama Pokua Fenny and Ernest Aryeetey (2008). China-Africa Relations: A Case Study of Ghana. Prepared for the African Economic Research Consortium.

Whitfield, Lindsay (2009), "'Change for a better Ghana': Party Competition, Institutionalization and Alternation in Ghana's 2008 Elections", African Affairs $108,621-41$. 